\title{
The role of computational analysis in aortic dissection
}

\section{Elnur Smajić ${ }^{\star *}$ \\ Nihad Mešanović ${ }^{1}$ \\ Daniela Lončar ${ }^{1}$ Azur Latifagić ${ }^{2}$}

1The Public Health Institution University Clinical Center Tuzla, Tuzla, Bosnia and Herzegovina

${ }^{2}$ Private Medical Clinic „Moja klinika", Sarajevo, Bosnia and Herzegovina
RECEIVED:

April 14, 2015

ACCEPTED:

April 20, 2015
KEYWORDS: aortic dissection, computer aided detection, computational analysis. CITATION: Cardiol Croat. 2015;10(3-4):91. | DOI: http://dx.doi.org/10.15836/ccar.2015.91

ORCID: Elnur Smajić, http://orcid.org/0000-0003-0881-9443 • Nihad Mešanović, http://orcid.org/0000-0003-1912-1155 • Daniela Lončar, http://orcid.org/0000-0003-1496-9309 • Azur Latifagić, http://orcid.org/0000-0001-5300-3289

*ADDRESS FOR CORRESPONDENCE: Elnur Smajić, Javna zdravstvena ustanova Univerzitetski klinički centar Tuzla, Trnovac bb, 75000 Tuzla, Bosnia and Herzegovina. Phone: +387-61-185-437. E-mail: elnur.smajic@ukctuzla.ba

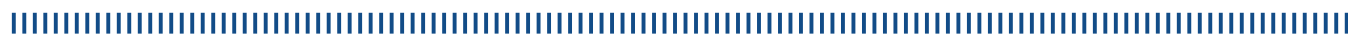

Acute aortic dissection is the most frequent and most dangerous manifestation of the so-called acute aortic syndrome. In its natural evolution, without treatment, acute aortic dissection type A has a mortality rate of about 1\% per hour initially, with dead outcome expectancy of more than $50 \%$ of the patients by the 3rd day after initial diagnosis, and almost $80 \%$ by the end of the 2 nd week. Death rates are lower but still significant in acute type B aortic dissection: $10 \%$ death rate for patients at 30 days, and $70 \%$ death rate or more in the highest-risk groups.

The reliable identification of the true and false lumen is crucial for treatment planning. Three dimensional vascular reconstruction with vascular segmentation and centerline reconstructions are often helpful in aortic measurements for stent graft planning. The elasticity and mobility of the dissected septum tend to decrease over time and gradually increasing stiffness. Computational analysis can predict hemodynamic status of the true lumen, false lumen, entry, reentry tear and wall shear stress. However, this task is a difficult and time-consuming even for trained cardiologists and engineers. A Computer Aided Detection (CAD) system needs to be capable to display the different lumina, and hemodynamic status of them in an easily comprehensible way to help the physicians in setting the right diagnosis. Using multislice computer tomography data, aortic dissection can be detected by checking for an abnormal shape of the aorta using edge detection methods. Integration of knowledge between diverse scientific fields is essential (i.e., engineering, informatics and medicine).

CAD established its role in medical imaging and steps forward to fill the new, more demanding positions in medical practice. On the one hand, aortic dissection represent a diagnostic and therapeutic challenge for cardiologists, but on the other hand the progress of CAD is particularly important in the diagnosis and treatment of aortic dissection. ${ }^{1-4}$

LITERATURE IIIIIIIIIIIIIIIIIIIIIIIIIIIIIIIIIIIIIIIIIIIIIIIIIIIIIIIIIIIIIIIIIIIIIIIIIIIIIIIIIIIIIIIIIIIIIIIIIIIIII

1. Sherrah A, Grieve S, Jeremy R, Bannon P, Vallely M, Puranik R. MRI in chronic aortic dissection: a systematic review and future directions. Front Cardiovasc Med. 2015;2:5. DOI: http://dx.doi.org/10.3389/fcvm.2015.00005

2. van Bogerijen GHW, Tolenaar JL, Conti M, Auricchio F, Secchi F, Sardanelli F, et al. Contemporary role of computational analysis in endovascular treatment for thoracic aortic disease. Aorta. 2013;1(3):171-81. DOI: http://dx.doi.org/10.12945/j.aorta.2013.13-003

3. Wan Ab Naim WN, Ganesan PB, Sun Z, Chee KH, Hashim SA, Lim E. A perspective review on numerical simulations of hemodynamics in aortic dissection. ScientificWorldJournal. 2014 Feb 3;2014:652520. DOI: http://dx.doi.org/10.1155/2014/652520

4. Goldstein SA, Evangelista A, Abbara S, Arai A, Asch FM, Badano LP, et al. Multimodality imaging of diseases of the thoracic aorta in adults: from the American Society of Echocardiography and the European Association of Cardiovascular Imaging: endorsed by the Society of Cardiovascular Computed Tomography and Society for Cardiovascular Magnetic Resonance. J Am Soc Echocardiogr. 2015;28(2):119-82. DOI: http://dx.doi.org/10.1016/j.echo.2014.11.015 